\title{
CRITICALITY ANALYSIS OF URANIUM STORAGE FACILITY WITH FORMATION RACKS
}

\author{
Sri Kuntjoro \\ Center for Technology and Nuclear Reactor Safety - BATAN \\ PUSPIPTEK, Building 80, Setu, Tangerang Selatan 15310 \\ e-mail: srikuncoro@batan.go.id, telp. : 021-7560912,fax: 021-7560913 \\ Diterima editor: 14 Februari 2017 \\ Diperbaiki: 1 Maret 2017 \\ Disetujui untuk publikasi: 2 Maret 2017
}

\begin{abstract}
CRITICALITY ANALYSIS OF URANIUM STORAGE FACILITY WITH FORMATION

RACKS. Uranium materials are needed for the uranium fuel production of research reactors and radioisotope. Before the uranium material is used, it is stored in the storage facility. One of the prerequisites for uranium material storage facilities is that it must be in the sub-critical condition. The purpose of this study is to analyze the criticality condition of uranium material storage facility located in PT. Inuki (Persero) and to ensure that the criticality condition is always in sub-critical state. Criticality analysis was performed using MCNP-5 program to determine the level of criticality of the three uranium material storage facilities at initial conditions and conditions after adding the storage racks. For analysing storage facilities 1 and 2 , three scenarios of container on the storage rack formations were considered. Meanwhile, for analysing the storage facility 3, one scenario was considered. The results confirm that all strorages at initial condition and after adding storage racks formation were still in sub-critical condition $(\mathrm{k}$-eff $<1)$. These results are then used as the basis for the uranium materials management. It is also used as a basis for issuing an operational license by the nuclear energy regulatory body (BAPETEN).
\end{abstract}

Key words : criticality, uranium storage facility, $k$-eff

\section{ABSTRAK}

ANALISIS KRITIKALITAS DI FASILITAS PENYIMPANAN BAHAN URANIUM DENGAN FORMASI PENGATURAN RAK. Bahan uranium dibutuhkan untuk produksi bahan bakar reaktor penelitian dan radioisotop. Bahan uranium sebelum digunakan terlebih dahulu disimpan pada fasilitas penyimpanan. Salah satu prasyarat fasilitas penyimpanan bahan uranium adalah fasilitas tersebut harus dalam kondisi sub-kritis. Bila kondisi kritis terjadi mengakibatkan proses fissi pada bahan uranium tidak terkendali, sehingga akan menimbulkan suhu yang sangat tinggi. Tujuan dari penelitian ini adalah untuk menganalisa kondisi kritikalitas dari fasilitas penyimpanan bahan uranium yang berada di PT. INUKI (Persero) untuk menjamin fasilitas tersebut dalam kondisi sub-kritis. Analisis kritikalitas dilakukan menggunakan program MCNP-5 untuk mengetahui tingkat kritikalitas dari tiga fasilitas penyimpanan bahan uranium untuk kondisi awal dan kondisi setelah ditambahkan rak penyimpanan. Untuk fasilitas penyimpanan 1 dan 2 dibuat tiga skenario pengaturan container pada rak penyimpanan, sedangkan pada fasilitas penyimpanan 3 dilakukan 1 skenario. Hasil ini menunjukkan seluruh fasilitas penyimpanan pada kondisi awal dan setelah ditambah rak penyimpanan dalam kondisi sub-kritis (k-eff<1). Hasil tersebut selanjutnya dipergunakan sebagai dasar untuk menyusun manejemen pengelolaan bahan uranium. Selain itu juga digunakan sebagai dasar untuk pembuatan ijin dari badan pengawas (BAPETEN).

Kata Kunci : kritikalitas, fasilitas penyimpanan berbahan uranium, $k$-eff 


\section{INTRODUCTION}

Radioisotope and fuel production require low enriched uranium (LEU). Uranium materials require storage facility prior to use. Storages of uranium materials have prerequisites, among others, where it should be in a sub-critical condition. These prerequisites must be satisfied since if critical conditions occur, it will cause the uncontrolled fission on uranium material. As a result, a high heat is generated in the uranium material, which could melt the uranium material itself. Melting of uranium materials will lead to the release of fission products in the form of radioactive materials into the environment and can be hazardous to people as well as the environment.

Criticality calculations are performed at nuclear facilities, fuel storage, and storage of uranium materials. The analysis was performed to ensure existing facilities in sub-critical condition to avoid uncontrolled fission reactions and high temperature in the facilities. Criticality calculations can be done using a variety of computer program such as MCNP-5 computer code, which is based on Monte Carlo method [1]. Critical analysis on various cases have been done by previous investigators, for example, on various geometry fuel arrangement by Doddy Kastanya [2], TRIGA Mark II reactor first criticality by D. Alloni et.al [3], as well as the fuel storage facility at the TRIGA Mark II research reactor by Loren R Metthew [4]. It also has been carried out for criticality calculation of high temperature reactors, research reactors and other criticality problems. Criticality calculations for high temperature power reactor as for the pebble and HTR reactor criticality has been conducted by Meng-Jen W, et al, Meng-Jen W, et al, Evi Setiawati, at al and several other researchers [5-11]. For the calculation of criticality at research reactor as in the Ghana LEU research reactor has been conducted by Henry Cecil O [12]. In addition, the calculation of the other criticality calculations for effect of difference nuclear library, influence of normalization flux and influence of geometry models have been done by R. Mosteller et al, Gasper Zerovnik and Christopher R. Hughes, et al respectively [13-15].

Criticality research has been done around the reactors and spent fuel storage facility and no one has been done on uranium material storage facilities. The purpose of this study was to analyse the criticality condition of the uranium material storage facility in the PT. INUKI (Persero). This study was conducted to determine the criticality condition of the storage facilities 1,2 and 3 at the initial conditions and at the condition with additional storage racks. At the storage facility 1 and 2 , which contain storage racks, analysis was made in three scenarios, while for the storage facility 3 was made just one scenario.

The first step in this analysis is to make the cell calculation model for uranium material that will be stored in a storage facility. Furthermore, the density atom calculations are performed for all material in the cell calculation. Atomic density calculations are also done for all material in the system calculation. The Atomic density obtained in the cell and system model are used as an input to the MCNP-5 codes. Both of these inputs are used in the calculation of criticality of the system storage facility for the current condition and the condition after storage racks are installed. Further analysis is to determine the level of criticality of the system of fuel storage facility for the current condition and the condition after storage racks. Results are used for the fuel management as well as the basis for uranium materials management license from the regulatory body (BAPETEN/Indonesia Nuclear Energy Regulatory Agency)

\section{THEORY}

\section{MNCP-5 Computer Program}

Criticality analysis can be performed using a MCNP-5 program package. MCNP-5 is a computer program used to analyze the particle flux by the Monte Carlo method. Monte Carlo method is a method of solving the problem of neutron transport in a way to simulate the trail of particles to follow the lead of the particles since the "birth" followed step by step in a medium that has been defined until the neutron particles are diminished from the medium, followed by other particles sequentially. For neutron flux calculation, a library of cross-section for the medium 
through which the particles neutrons $(\sigma 1, \sigma 2, \sigma 3 \ldots)$ has been available in the package, while the probability of particles neutrons interacting medium that is passed is determined randomly by plant random number (random number generator), for it takes the density of the medium as an the program. The number of neutron particle that passes through a medium is calculated (scored), the number of neutrons is the neutron flux at the point observed[1].

Precision of the calculation packages of MCNP-5 program is determined by three parameters, namely;

a. The error relative to the 1-sigma standard deviation, which is defined as:

$$
R=\frac{S_{\bar{x}}}{\bar{x}}
$$

with $S_{\bar{x}}$ is the standard deviation, $\bar{x}$ is the price of the average flux count. Calculations with location detection point (point detector) is considered to meet the criteria if $\mathrm{R}<0,05$.

b. Variance of Variance (VOV), which is defined as;:

$$
V O V=\frac{\sum_{i=1}^{C}\left(x_{i}-\bar{x}\right)^{2}}{\left[\sum_{i=1}^{C}\left(x_{i}-\bar{x}\right)^{2}\right]^{2}}=\frac{1}{C}
$$

where $\mathrm{C}$ is a count of particles. Calculations with accuracy MVNP considered eligible if the VOV value is $<0,1$.

c. Figure of Merit (FOM), which is defined as;:

$$
F O M=\frac{1}{R T}
$$

where $\mathrm{T}$ is simulation time. The results of computer simulations considered carefully when FOM is relatively constant value for each sequence capture particles traced. If the parameter is not reached, then calculation is repeated by adding traced neutron or computer calculation time until the parameter value is reached.

d. Geometry and Cross-section data

Input data for MCNP-5 code are comprised of the geometry specification and the cross-section data. The required data of the geometry specification involves of the 2 or 3 dimensional geometric shapes, the volume of material composition and also the material mass. For the cross-section data require the material composition, the energy for neutron fission reaction and the cross-section data library as a function of energy

\section{Determination of the mass fraction and volume fraction and atomic densitiy of chemical elements of a material}

The mass, mass fraction, volume fraction and atomic density of a chemical element are required as inputs to the MCNP-5 computer program. The chemical element is a medium through which a neutron particle. It is an observation point where there is a trail of neutron from birth until it disappeared from the media. To determine the mass fraction and the volume fraction, the atomic density building blocks of matter is required. The material volume data is also required. The formula for determining the mass fraction, volume fraction and the atomic density are as follows.

For example, the material of $\mathrm{UO}_{2}$ has a density $\rho\left(\mathrm{uo}_{2}\right)\left(\mathrm{g} / \mathrm{cm}^{3}\right)$, with enrichment of $\omega \%$ and Molar weigh of $\mathrm{UO}_{2}, \mathrm{U}, \mathrm{U}-235, \mathrm{U}-238$ and Oxigen are $\mathrm{M}\left(\mathrm{UO}_{2}\right), \mathrm{M}(\mathrm{U}), \mathrm{M}(\mathrm{U}-235), \mathrm{M}(\mathrm{U}-$ $238)$ and $\mathrm{M}(\mathrm{O})$ respectively, then the steps are:

- Determining the mass of material (gram)

$$
\begin{gathered}
\text { Mass of } U=\frac{\omega \times M(U-235)+(1-\omega) \times M(U-238)}{\omega \times M(U-235)+(1-\omega) \times M(U-238)+2 \times M(0)} \text { mas of } \mathrm{UO}_{2} \\
\text { Mass of Oxygen }=\frac{\mathrm{M}(0)}{\omega \times \mathrm{M}(\mathrm{U}-235)+(1-\omega) \times \mathrm{M}(\mathrm{U}-238)+2 \mathrm{XM}(0)} \times \text { mass of } U-235=\omega \times \mathrm{UO}_{2} \\
\text { mass of } \mathrm{U}
\end{gathered}
$$




$$
\text { mass of } U-238=(1-\omega) \times \text { Mass of } U
$$

- Determining the mass fraction and volume fraction of material

$$
\begin{gathered}
\text { mass fraction of } U-235=\frac{\text { mass of } U-235}{\text { Mass of } \mathrm{UO}_{2}} \\
\text { mass fraction of } U-238=\frac{\text { mass of } U-238}{\text { Mass of } \mathrm{UO}_{2}} \\
\text { Volume fraction of } \mathrm{U}=\frac{\text { Mass of } U / \text { density of } U}{\text { Mass of } \mathrm{UO}_{2} / \text { density of } U \mathrm{O}_{2}}
\end{gathered}
$$$$
\text { Volume fraction of Oksigen }=1-\text { Volume fraction of } U
$$

- Determining the atomic density (atom $\left./ \mathrm{cm}^{3}\right)$

$$
\begin{aligned}
& \text { Number density of } U-235=\omega \times \rho(\mathrm{uo} 2) / \mathrm{M}(\mathrm{U}-235) \times\left(\frac{\mathrm{M}(\mathrm{U})}{\mathrm{M}\left(\mathrm{UO}_{2}\right)}\right) \\
& \text { Number density of } \mathrm{U}-238=\omega \times \rho(\mathrm{uo} 2) / \mathrm{M}(\mathrm{U}-238) \times\left(\frac{\mathrm{M}(\mathrm{U})}{\mathrm{M}\left(\mathrm{UO}_{2}\right)}\right) \\
& \text { Number density of Oxygen }=\omega \times \rho(\mathrm{uo} 2) / \mathrm{M}(\mathrm{O}) \times\left(\frac{\mathrm{M}(\mathrm{U})}{\mathrm{M}\left(\mathrm{UO}_{2}\right)}\right)
\end{aligned}
$$

\section{METHODOLOGY}

\section{CELL MODEL FOR URANIUM}

The uranium cell consists of two types of cylindrical containers, which are made of uranium, of which 1 piece of container is loaded with natural $\mathrm{UO}_{2}$ with mass of $1.273 \mathrm{~kg}$ and 1 piece of container loaded with depleted uranium metal with mass of $3.576 \mathrm{~kg}$. Each container has a diameter of $14 \mathrm{~cm}$ and $17 \mathrm{~cm}$, respectively.

\section{SYSTEM MODEL FOR THREE STORAGE FACILITIES}

\section{System Model for Current Storage Facility}

\section{Sorage Facility 1}

Storage facility 1 is a room measuring of $3.36 \mathrm{~m}$ long, $3.10 \mathrm{~m}$ wide and $5.25 \mathrm{~m}$ high. Storage facility 1 in the current condition contains 10 pieces of containers loaded with natural UO2 each of mass $1.273 \mathrm{~kg}$ and 10 containers loaded with depleted uranium metal each of mass 3.576 $\mathrm{kg}$. Each container has a diameter of $14 \mathrm{~cm}$ and $17 \mathrm{~cm} \mathrm{[16].} \mathrm{Each} \mathrm{container} \mathrm{has} \mathrm{designed} \mathrm{of} 30 \mathrm{~cm}$ distance from each other. The container is made of plastic.

\section{Storage Facility 2}

Storage facility 2 is a room measuring of $3.36 \mathrm{~m}$ long, $3.10 \mathrm{~m}$ wide and $5.25 \mathrm{~m}$ high. The storage facility 2 currently contains five pieces of container loaded with natural UO2 each of mass $0.106 \mathrm{~kg}$ and 5 pieces of container loaded with a mass of $18.418 \mathrm{~kg}$ UF4. Each container has a diameter of $30 \mathrm{~cm}$ and $34 \mathrm{~cm}$ high [16]. Each container has been designed to have a space of $70 \mathrm{~cm}$ from each other. The container is made of iron. 


\section{Storage Facility 3}

The storage facility 3 is a room measuring of $3.36 \mathrm{~m}$ long, $3.10 \mathrm{~m}$ wide and $5.25 \mathrm{~m}$ high. The condition of storage facility 3 currently contains 20 pieces of container-laden natural UCaF2 each of mass $2.373 \mathrm{~kg}$ with $19.75 \%$ enrichment; and 20 pieces of metal container-laden with uranium enrichment, $19.75 \%$ enrichment with the mass of $7.111 \mathrm{~kg}$. Model calculations can be seen in Figure 4. Each container has a diameter of $10 \mathrm{~cm}$ and $23 \mathrm{~cm}$ high [16]. Each container has been designed of a space $30 \mathrm{~cm}$ from each other. The container is made of iron.

\section{System Model with Storage Racks}

\section{Storage Facility 1}

Storage facility 1 was designed to contain 2 storage racks separated by a distance of $1 \mathrm{~m}$. Each storage rack consists of 3 levels of shelves.

The ground floor of each shelf contains $2 \times 4$ units of container and each container of $30 \mathrm{~cm}$ diameter and $70 \mathrm{~cm}$ high. The container which is located on the ground floor, on the first shelf and the second shelf were loaded with UCaF2 with mass of $2.373 \mathrm{~kg}$ with $19.75 \%$ enrichment and $7.111 \mathrm{~kg}$ uranium metal with $19.75 \%$ enrichment [16]. Each container has designed of $50 \mathrm{~cm}$ apart from each other.

Furthermore, every shelf level consists of $3 \times 6$ containers. Containers at all shelves are 14 $\mathrm{cm}$ in diameter and $17 \mathrm{~cm}$ high. Each container is separated by $39.5 \mathrm{~cm}$. All containers made of iron.

a. The first scenario

- $\quad$ The ground floor contains $2 \times 4$ containers, 4 containers were each loaded with $\mathrm{UCaF}_{2} \mathrm{mass}$ of $2.373 \mathrm{~kg}$ with $19.75 \%$ enrichment, and 4 other containers each loaded with metal Uranium mass of $7.111 \mathrm{~kg}$ with $19.75 \%$ enrichment.

- The first rack and a second rack each consisting of three shelves. The first to third shelves, where contain of 6 containers each. The entire racks contain of 36 containers with the mass of each container was $1.273 \mathrm{~kg}$ of natural $\mathrm{UO}_{2}$.

b. The second scenario

- The ground floor contains $2 \times 4$ containers, 4 containers each loaded with $2.373 \mathrm{~kg} \mathrm{UCaF}_{2}$ with $19.75 \%$ enrichment, and 4 other containers each loaded with $7.111 \mathrm{~kg}$ metal Uranium with $19.75 \%$ enrichment.

- The first and the second rack consist of three shelves. All shelves contain 6 containers each. The entire rack contains 36 containers where each container has $3.576 \mathrm{~kg}$ natural uranium metal depletion.

c. The third scenario

- $\quad$ The ground floor of each rack contains $2 \times 4$ containers, 4 containers each loaded with 2.373 $\mathrm{kg} \mathrm{UCaF} 2$ with $19.75 \%$ enrichment, and 4 other containers each loaded with $7.111 \mathrm{~kg}$ metal Uranium with $19.75 \%$ enrichment.

- The first rack contain 3 shelves, each shelf contains 6 containers and each container containing $1.273 \mathrm{~kg}$ of natural $\mathrm{UO}_{2}$. The entire first rack consists of 18 containers.

- The second rack contain 3 shelves, each shelf contains 6 containers and each container containing $3.576 \mathrm{~kg}$ of natural uranium metal depletion. The entire second rack consists of 18 containers.

\section{Storage Facility 2}

Storage facility 2 was designed to contain 2 storage racks that separated by a distance of $1 \mathrm{~m}$. Each storage rack comprises of a base and two levels of shelves.

The ground floor of each shelf hold $2 \times 4$ pieces of containers and each container has $30 \mathrm{~cm}$ diameter and $70 \mathrm{~cm}$ high. On the first and the second shelf were loaded with $2.373 \mathrm{~kg} \mathrm{UCaF} \mathrm{Uith}_{2}$ $0.7 \%$ enrichment and $7.111 \mathrm{~kg}$ uranium metal with $0.7 \%$ enrichment. Each container was $50 \mathrm{~cm}$ apart from each other. 
Furthermore, each level consists of a rack $2 \times 4$ containers. The diameter and height of each container is $30 \mathrm{~cm}$ and $34 \mathrm{~cm}$ respectively. Each container as far apart as $50 \mathrm{~cm}$ and containers made of iron.

a. The first scenario

- The ground floor contains $2 \times 4$ container, 4 containers were loaded with $2.373 \mathrm{~kg} \mathrm{UCaF}_{2}$ with $19.75 \%$ enrichment, and 4 other containers loaded with $7.111 \mathrm{~kg}$ metal Uranium with $19.75 \%$ enrichment.

- The first rack and a second rack consist of 2 shelves. Each shelf contains of 4 containers. The entire racks contain of 16 containers, each container has $0.106 \mathrm{~kg}$ of natural $\mathrm{U}_{3} \mathrm{O}_{8}$.

b. The second scenario

- The ground floor contains $2 \times 4$ container, 4 containers were loaded with $2.373 \mathrm{~kg} \mathrm{UCaF}_{2}$ with $19.75 \%$ enrichment, and 4 other containers loaded with $7.111 \mathrm{~kg}$ metal Uranium with $19.75 \%$ enrichment.

- The first rack and a second rack each consisting of 2 shelves. Each shelf contains of 4 containers. The entire racks contain of 16 containers, each container has $18.418 \mathrm{~kg}$ of natural $\mathrm{UF}_{4}$.

c. The third scenario

- The ground floor of each rack of $2 \times 4$ containers, 4 containers each charged $\mathrm{UCaF}_{2}$ mass of $2.373 \mathrm{~kg}$ with $19.75 \%$ enrichment, and 4 other containers each charged metal Uranium enrichment mass of $7.111 \mathrm{~kg}$ with $19.75 \%$.

- The first rack consists of 2 shelves. Each shelf contains of 4 containers. The entire racks contain of 8 containers, each container has $0.106 \mathrm{~kg}$ of natural $\mathrm{U}_{3} \mathrm{O}_{8}$

- The second rack consisits 2 shelves. Each shelf contains of 4 containers. The entire racks contain of 8 containers, each container has $18.418 \mathrm{~kg}$ of natural $\mathrm{UF}_{4}$.

\section{Storage Facility 3}

Storage facility 3 was designed to contain 2 storage racks that separated by a distance of $1 \mathrm{~m}$. Each storage rack is consisting of the base and 3 levels of shelves.

The ground floor of each shelf was containing $3 \times 6$ pieces of container and each container of $30 \mathrm{~cm}$ diameter and $70 \mathrm{~cm}$ high. The container which is located on the ground floor, on the first shelf and the second shelf were loaded with $\mathrm{UCaF}_{2}$ with mass of $2,373 \mathrm{~kg}$ with $19.75 \%$ enrichment and $7.111 \mathrm{~kg}$ uranium metal with $19.75 \%$ enrichment. Each container was $50 \mathrm{~cm}$ apart from each other.

Furthermore, every shelf level consists of $(3 \times 6)$ containers. Containers at the entire shelves have $14 \mathrm{~cm}$ in diameter and $17 \mathrm{~cm}$ high. Each container is separated by $39.5 \mathrm{~cm}$ and containers made of iron.

The first scenario

- $\quad$ The ground floor contains $2 \times 4$ containers, 4 containers each loaded with $2,373 \mathrm{~kg} \mathrm{UCaF}_{2}$ with $19.75 \%$ enrichment, and 4 other containers each loaded with $7.111 \mathrm{~kg}$ metal Uranium with $19.75 \%$ enrichment.

- The first rack and a second rack each consisting of three shelves: the first shelf to the third shelf, where every shelf contains 6 containers. The entire rack contains 36 containers with each container has $5.337 \mathrm{~kg}$ of $\mathrm{U}_{3} \mathrm{Si}_{2} 19.75 \%$ enrichment.

\section{RESULTS AND DISCUSSION}

\section{CELL MODEL FOR URANIUM}

In Figure 1, it is shown in the left-hand side the model for a front view of the container, while the right image is modeling for top view of the container. Red color indicates a material homogenization of uranium materials inside the container and blue is the homogenization of the material contained. 


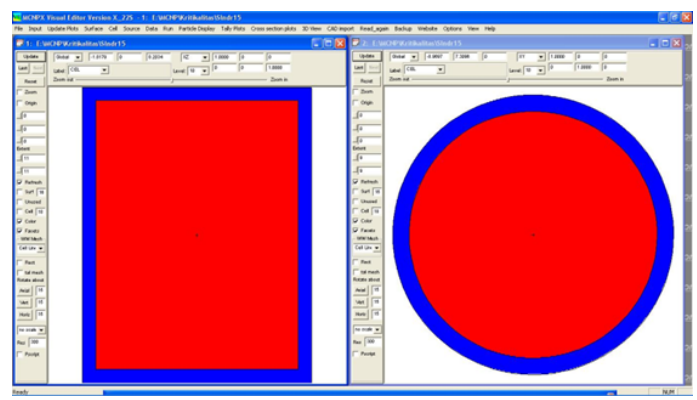

Figure 1. The cell model for uranium materials

\section{SYSTEM MODEL FOR THREE STORAGE FACILITIES}

\section{System Model for Initial Condition Storage Facility}

\section{Sorage Facility 1}

Figure 2 in the left hand-side shows the image model of the view from the front, while in the right-hand side shows a view from above. Figure 2 represents the material uranium only in one level and consists of two types (natural $\mathrm{UO}_{2}$ and depleted uranium metal), and each type consisting of $2 \times 5$ container.

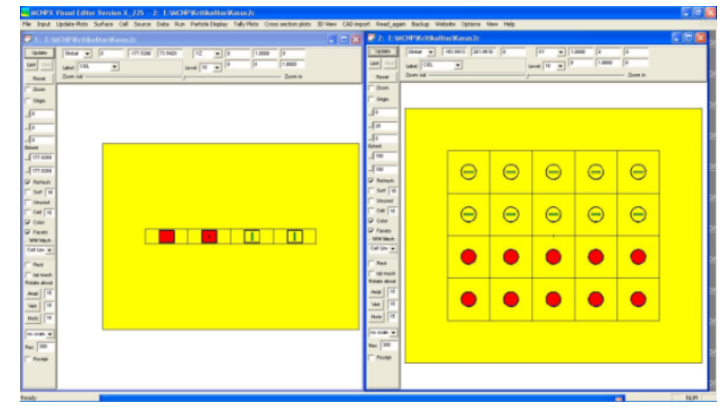

Figure 2. System model for a storage facility 1 in the current condition

\section{Storage Facility 2}

Figure 3 depicts the view from the front (left-hand side), whiles the image to the righthand side, and shows a view from above. Figure 3 represents material uranium only in one level and consists of two types (natural $\mathrm{UO}_{2}$ and $\mathrm{UCaF}_{2}$ ), and each type is composed of five containers.

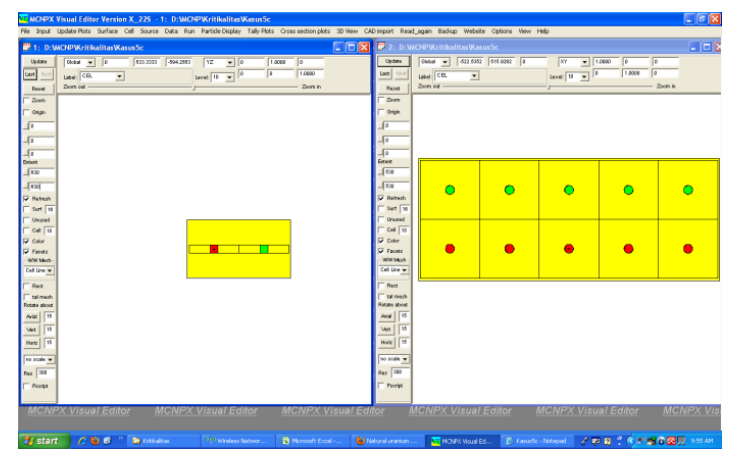

Figure 3. System model for storage facility 2 in current condition 


\section{Storage Facility 3}

Figure 4 shows for the image model of the view from the front (left-hand side), while the model image to the right, shows a view from above. Figure 4 represents the material uranium only in one level and consists of two types (natural $\mathrm{UCaF}_{2}$ and uranium metal), and each consisting of $4 \times 5$ container types.

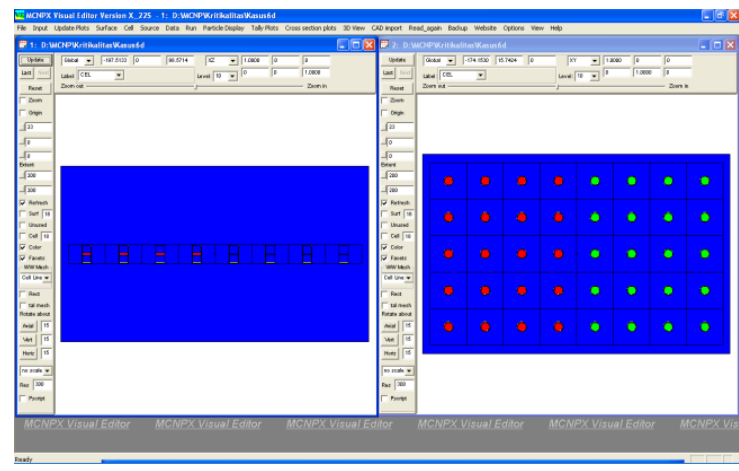

Figure 4. System model for the storage facility 3 in current condition

\section{System Model with Storage Racks}

\section{Storage Facility 1}

Figure 5 shows the first rack, which is represented by models 1 (front view) and 2 (side view), and the second rack, which is represented by models 3 (front view) and 4 (side view). It is shown in Figure 5 also that uranium materials at a lower shelf consist of 2 uranium types ( $\mathrm{UCaF}_{2}$ and uranium metal). Each shelf consisted of four containers. In the entire three shelves consists of one type of uranium $\left(\mathrm{UO}_{2} /\right.$ uranium metal), and was simulated into three scenarios. Scenario 1: the entire racks consist of $\mathrm{UO}_{2}$ and contain 36 containers. Scenario 2: the entire racks consist of uranium metal and contain 36 containers. Scenario 3: The entire first rack consists of $\mathrm{UO}_{2}$ (18 containers) and the entire second rack consists of ranium metal (18 containers).

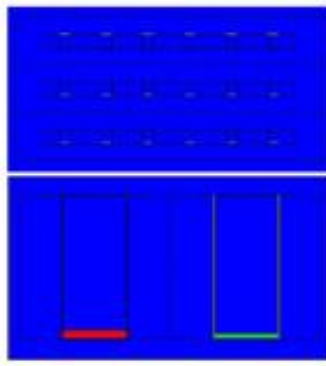

1

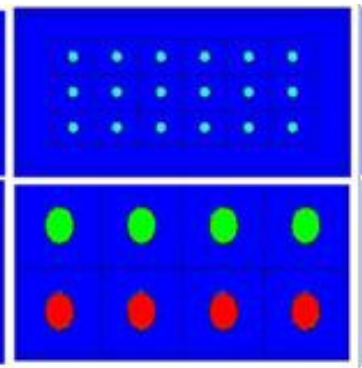

2

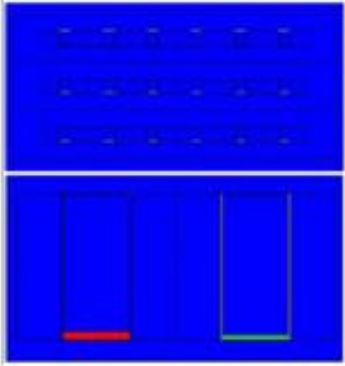

3

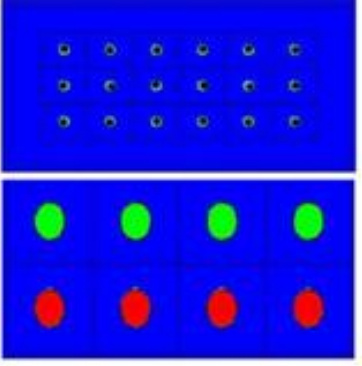

4

Figure 5. System model for storage facility 1 with first and second racks

\section{Storage Facility 2}

Figure 6 depicts the first rack, which is represented by models 1 (front view) and 2 (side view), and the second rack, which is represented by models 3 (front view) and 4 (side view). It is also shown in Figure 5 that uranium materials at lower shelf consists of 2 uranium types $\left(\mathrm{UCaF}_{2}\right.$ and uranium metal). In the entire racks consists of one type of uranium $\left(\mathrm{U}_{3} \mathrm{O}_{8} / \mathrm{UF}_{4}\right)$, and 
was simulated into three scenarios. Scenario 1: the entire racks consist of $\mathrm{U}_{3} \mathrm{O}_{8}$ and contain 16 containers. Scenario 2: The entire racks consist of $U_{4}$ and contain 16 containers. Scenario 3: The entire first rack consists of $\mathrm{U}_{3} \mathrm{O}_{8}$ (8 containers) and the entire second rack consists of $\mathrm{UF}_{4}(8$ containers).
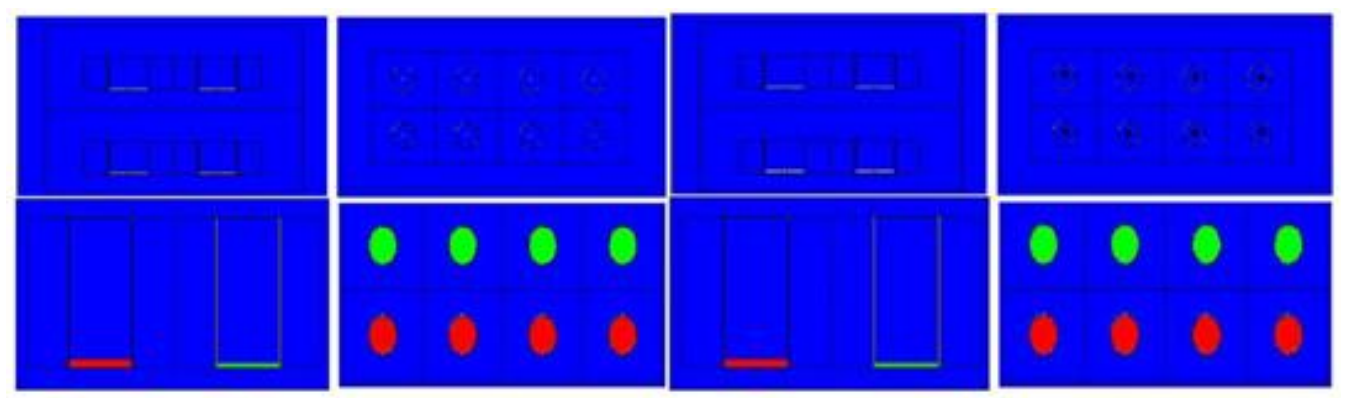

Figure 6. The system models the storage facility with the first rack and a second rack

\section{Storage Facility 3}

Figure 7 depicts the first rack, which is represented by models 1 (front view) and 2 (side view), and the second rack, which is represented by models 3 (front view) and 4 (side view). It is also shown in Figure 5 that uranium materials at lower shelf consists of 2 uranium types $\left(\mathrm{UCaF}_{2}\right.$ and uranium metal). On the third level rack consists of one type of material uranium $\left(\mathrm{U}_{3} \mathrm{Si}_{2}\right)$, and simulated into one scenario that is the entire shelf in the entire rack consists $\mathrm{U}_{3} \mathrm{Si}_{2}$ in 36 containers.
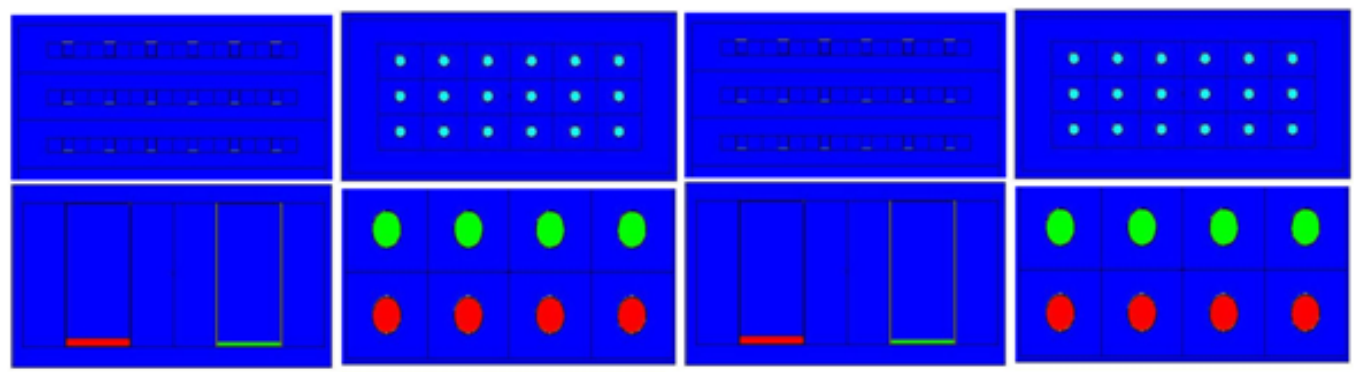

Figure 7. The system models the third storage facility with the first rack and a second rack

Futhermore after all the model is defined, the calculation is carried to determine the volume fraction and the density of atoms for every material used in the storage facilities 1,2 and 3 using the formula (4) to (11) and the results can be seen in Table 1, 2 and 3.

Table 1. Material input MCNP-5 for the initial condition of storage facilities 1

\begin{tabular}{ccccccc}
\hline Material & $\begin{array}{c}\text { Mass of } \\
\text { Atom }\end{array}$ & $\begin{array}{c}\text { Density } \\
\left(\mathrm{gram} / \mathrm{cm}^{3}\right)\end{array}$ & $\begin{array}{c}\text { Enrichment } \\
(\%)\end{array}$ & $\begin{array}{c}\text { Mass } \\
(\text { gram })\end{array}$ & $\begin{array}{c}\% \\
\text { Weight }\end{array}$ & $\begin{array}{c}\text { Atomic } \\
\text { Density }\end{array}$ \\
\hline $\mathbf{U O}_{2}$ & - & 10.97 & 0.70 & 1273 & & - \\
$\mathrm{U}$ & 237.45 & 11.3 & - & - & & - \\
$\mathrm{U}-235$ & 235.04 & - & - & - & 0.007 & $1.28 \mathrm{E}-04$ \\
$\mathrm{U}-238$ & 238.05 & - & - & - & 0.993 & $1.79 \mathrm{E}-02$ \\
$\mathrm{O}$ & 16.00 & - & - & - & & $2.44 \mathrm{E}-03$ \\
$\mathrm{~N}$ & 14.00 & - & - & - & & $3.89 \mathrm{E}-10$ \\
$\mathrm{C}$ & 12.00 & - & & & &
\end{tabular}

Plastic 


\begin{tabular}{|c|c|c|c|c|c|c|}
\hline Material & $\begin{array}{c}\text { Mass of } \\
\text { Atom }\end{array}$ & $\begin{array}{c}\text { Density } \\
\left(\mathrm{gram} / \mathrm{cm}^{3}\right)\end{array}$ & $\begin{array}{c}\text { Enrichment } \\
(\%)\end{array}$ & $\begin{array}{l}\text { Mass } \\
\text { (gram) }\end{array}$ & $\begin{array}{c}\% \\
\text { Weight }\end{array}$ & $\begin{array}{l}\text { Atomic } \\
\text { Density }\end{array}$ \\
\hline $\mathrm{C}$ & 12.00 & & & & 0.8562 & - \\
\hline $\mathrm{H}$ & 1.01 & & & & 0.1438 & - \\
\hline U metal & - & 18.95 & 0.07 & 3576 & & - \\
\hline U-235 & 235.04 & - & - & - & 0.007 & $6.14 \mathrm{E}-04$ \\
\hline U-238 & 238.05 & - & - & - & 0.993 & $8.68 \mathrm{E}-02$ \\
\hline Air & - & 0.0012 & - & - & & - \\
\hline $\mathrm{C}$ & 12.00 & - & - & - & & $7.45 \mathrm{E}-06$ \\
\hline $\mathrm{N}$ & 14.00 & - & - & - & & $3.84 \mathrm{E}-05$ \\
\hline $\mathrm{O}$ & 16.00 & - & - & - & & $1.03 \mathrm{E}-05$ \\
\hline $\mathrm{Ar}$ & 39.95 & - & - & - & & $2.28 \mathrm{R}-07$ \\
\hline $\mathrm{Ne}$ & 20.17 & - & - & - & & $4.24 \mathrm{E}-10$ \\
\hline $\mathrm{He}$ & 4.00 & - & - & - & & $1.25 \mathrm{E}-10$ \\
\hline $\mathrm{Kr}$ & 83.78 & - & - & - & & $2.55 \mathrm{E}-11$ \\
\hline $\mathrm{H}$ & 1.01 & - & - & - & & $4.19 \mathrm{E}-13$ \\
\hline $\mathrm{Xe}$ & 131.26 & - & - & - & & $2.17 \mathrm{E}-12$ \\
\hline
\end{tabular}

Table 1 shows that the material, which can be stored in Storage Facility 1 are $\mathrm{OU}_{2}$ with 1273 gr mass and Uranium Metal with 3576 gr mass. Two uranium types, which will be placed in container, are built from plastic material. $\mathrm{OU}_{2}$ material consists of $1.28 \mathrm{E}-04$ atom $/ \mathrm{cm}^{3}$ of U-235 and $7.21 \mathrm{E}-03$ atom $/ \mathrm{cm}^{3}$ of U-238 and uranium metal consists of $6.14 \mathrm{E}-04$ atom $/ \mathrm{cm}^{3}$ of U-235 and $8.68 \mathrm{E}-02$ atom $/ \mathrm{cm}^{3}$ of $\mathrm{U}-238$. This case shows that the $\mathrm{U}-235$ mass in $\mathrm{UO}_{2}$ and uranium metal material is very small compare to the U-238 mass. It is because the enrichment of uranium in $\mathrm{UO}_{2}$ and uranium metal is quite small at $0.7 \%$. It also shows that the number of U-235 in uranium metal more than in $\mathrm{UO}_{2}$, this is because the uranium metal mass is greater than the $\mathrm{UO}_{2}$ mass.

Table 2. Material input MCNP-5 for initial conidition of storage facilities 2

\begin{tabular}{|c|c|c|c|c|c|c|}
\hline Material & $\begin{array}{l}\text { Atomic } \\
\text { weight }\end{array}$ & $\begin{array}{c}\text { Density } \\
\left(\text { gram } / \mathrm{cm}^{3}\right)\end{array}$ & $\begin{array}{c}\text { Enrichmnt } \\
(\%)\end{array}$ & $\begin{array}{l}\text { Mass } \\
\text { (gram) }\end{array}$ & $\begin{array}{c}\% \\
\text { Weight }\end{array}$ & $\begin{array}{l}\text { Atomic } \\
\text { Density }\end{array}$ \\
\hline $\mathbf{U}_{3} \mathbf{O}_{8}$ & - & 8.30 & 0.70 & 106 & - & - \\
\hline $\mathrm{U}$ & 237.45 & 11.3 & - & - & - & - \\
\hline U-235 & 235.04 & - & - & - & - & $1.49 \mathrm{E}-06$ \\
\hline U-238 & 238.05 & - & - & - & - & 5.98E-06 \\
\hline $\mathrm{O}$ & 16.00 & - & - & - & - & $2.19 \mathrm{E}-04$ \\
\hline $\mathrm{N}$ & 14.00 & - & & - & - & $8.41 \mathrm{E}-06$ \\
\hline $\mathrm{C}$ & 12.00 & - & & - & - & $1.21 \mathrm{E}-05$ \\
\hline \multicolumn{7}{|l|}{ Container } \\
\hline $\mathrm{Fe}$ & 55.84 & 7.87 & - & - & - & - \\
\hline $\mathrm{UF}_{4}$ & - & 6.70 & 0.70 & 18984 & & - \\
\hline $\mathrm{U}-235$ & 235.04 & - & - & - & 0.007 & $1.04 \mathrm{E}-05$ \\
\hline U-238 & 238.05 & - & - & - & 0.993 & $1.46 \mathrm{E}-03$ \\
\hline $\mathrm{F}$ & 19.00 & - & - & - & - & $5.87 \mathrm{E}-03$ \\
\hline $\mathrm{C}$ & 12.00 & - & - & - & - & $4.81 \mathrm{E}-08$ \\
\hline $\mathrm{O}$ & 16.00 & - & - & - & - & $1.13 \mathrm{E}-08$ \\
\hline $\mathrm{N}$ & 14.00 & - & - & - & - & $6.96 \mathrm{E}-10$ \\
\hline Air & - & 0.0012 & - & - & - & - \\
\hline $\mathrm{C}$ & 12.00 & - & - & - & - & $7.45 \mathrm{E}-06$ \\
\hline $\mathrm{N}$ & 14.00 & - & - & - & - & $3.84 \mathrm{E}-05$ \\
\hline $\mathrm{O}$ & 16.00 & - & - & - & - & $1.03 \mathrm{E}-05$ \\
\hline Ar & 39.95 & - & - & - & - & 2.28R-07 \\
\hline $\mathrm{Ne}$ & 20.17 & - & - & - & - & $4.24 \mathrm{E}-10$ \\
\hline $\mathrm{He}$ & 4.00 & - & - & - & - & $1.25 \mathrm{E}-10$ \\
\hline $\mathrm{Kr}$ & 83.78 & - & - & - & - & $2.55 \mathrm{E}-11$ \\
\hline $\mathrm{H}$ & 1.01 & - & - & - & - & $4.19 \mathrm{E}-13$ \\
\hline $\mathrm{Xe}$ & 131.26 & - & - & - & - & $2.17 \mathrm{E}-12$ \\
\hline
\end{tabular}


Table 2 shows that the material, which can be stored in Storage Facility 1 , are $\mathrm{O}_{3} \mathrm{U}_{8}$ with 106 gr mass and $\mathrm{UF}_{4}$ with 18418 gr mass. Two uranium types, which will be placed in container, is built from plastic material. $\mathrm{O}_{3} \mathrm{U}_{8}$ material consists of $1.49 \mathrm{E}-06$ atom $/ \mathrm{cm}^{3}$ of $\mathrm{U}-235$ and $5.98 \mathrm{E}-06$ atom $/ \mathrm{cm}^{3}$ of U-238. While $\mathrm{UF}_{4}$ material consists of $1.04 \mathrm{E}-05$ atom $/ \mathrm{cm}^{3}$ of $\mathrm{U}-235$ and $1.46 \mathrm{E}-03$ atom $/ \mathrm{cm}^{3}$ of U-238. It also shows that the mass of U-235 on $\mathrm{UF}_{4}$ is greater than $\mathrm{U}_{3} \mathrm{O}_{8}$, this is due to the enrichment of both materials is the same, but the mass of $\mathrm{UF}_{4}$ has greater than the mass of $\mathrm{U}_{3} \mathrm{O}_{8}$.

Table 3. Material input MCNP-5 for initial condition of storage facilities 3

\begin{tabular}{|c|c|c|c|c|c|c|}
\hline Material & $\begin{array}{l}\text { Atomic } \\
\text { weight }\end{array}$ & $\begin{array}{c}\text { Density } \\
(\text { gram/cm } \\
\text { 3) }\end{array}$ & $\begin{array}{c}\text { Enrichment } \\
(\%)\end{array}$ & $\begin{array}{l}\text { Mass } \\
\text { (gram) }\end{array}$ & $\begin{array}{c}\% \\
\text { Weight }\end{array}$ & $\begin{array}{l}\text { Atomic } \\
\text { Density }\end{array}$ \\
\hline $\mathrm{U}_{3} \mathrm{Si}_{2}$ & - & 12.20 & 19.75 & 5337 & & - \\
\hline $\mathrm{U}$ & 237.45 & 11.3 & - & - & & - \\
\hline U-235 & 235.04 & - & - & - & 0.1975 & $4.24 \mathrm{E}-03$ \\
\hline U-238 & 238.05 & - & - & - & 0.8125 & $1.70 \mathrm{E}-02$ \\
\hline $\mathrm{Si}$ & 28.08 & - & - & - & & $1.67 \mathrm{E}-03$ \\
\hline $\mathrm{O}$ & 16.00 & - & - & - & & $8.21 \mathrm{E}-11$ \\
\hline $\mathrm{N}$ & 14.00 & - & & - & & $3.50 \mathrm{E}-10$ \\
\hline $\mathrm{C}$ & 12.00 & - & & - & & $5.06 \mathrm{E}-12$ \\
\hline \multicolumn{7}{|l|}{ Container } \\
\hline $\mathrm{Fe}$ & 55.84 & 7.87 & - & - & - & - \\
\hline Air & & 0.0012 & - & - & - & - \\
\hline $\mathrm{C}$ & 12.00 & - & - & - & - & $7.45 \mathrm{E}-06$ \\
\hline $\mathrm{N}$ & 14.00 & - & - & - & - & $3.84 \mathrm{E}-05$ \\
\hline $\mathrm{O}$ & 16.00 & - & - & - & - & $1.03 \mathrm{E}-05$ \\
\hline $\mathrm{Ar}$ & 39.95 & - & - & - & - & $2.28 \mathrm{R}-07$ \\
\hline $\mathrm{Ne}$ & 20.17 & - & - & - & - & $4.24 \mathrm{E}-10$ \\
\hline $\mathrm{He}$ & 4.00 & - & - & - & - & $1.25 \mathrm{E}-10$ \\
\hline $\mathrm{Kr}$ & 83.78 & - & - & - & - & $2.55 \mathrm{E}-11$ \\
\hline $\mathrm{H}$ & 1.01 & - & - & - & - & $4.19 \mathrm{E}-13$ \\
\hline $\mathrm{Xe}$ & 131.26 & - & - & - & - & $2.17 \mathrm{E}-12$ \\
\hline
\end{tabular}

Table 3 shows that the material, which can be stored in Storage Facility 1, is $\mathrm{O}_{3} \mathrm{Si}_{2}$ with 5337 gr mass. Only once uranium types, which will be placed in container, is built from iron. $\mathrm{O}_{3} \mathrm{Si}_{2}$ material consists of $4.24 \mathrm{E}-03$ atom $/ \mathrm{cm}^{3}$ of U-235 and $1.70 \mathrm{E}-02$ atom $/ \mathrm{cm}^{3}$ of U-238. Mass of U-235 in $\mathrm{U}_{3} \mathrm{Si}_{2}$ material has a large number, because the enrichment and mass of $\mathrm{U}_{3} \mathrm{Si}_{2}$ has a great values are $19.75 \%$ and 5330 grams respectively.

Of the three existing storage facilities, it is seen that the mass of uranium in each container in storage facility 3 is the largest U-235 mass compared to those in the storage facilities 1 and 2 . The large amount of U-235 will generate a large probability of fission reactions, so that a critical condition will occurs sooner. Therefore forming material in the storage facilities 3 should be more attention.

Further calculation is aimed to obtain the level of criticality of the storage facility 1 to 3 . The results obtained are presented in Table 4 to Table 6.

Table 4. Criticality level in storage facility 1

\begin{tabular}{clc}
\hline No. & \multicolumn{1}{c}{ Scenario } & K-eff \\
\hline 1 & Initial current condition & $0.48171 \pm 0.00155$ \\
2 & First scenario & $0.55478 \pm 0.00123$ \\
3 & Second scenario & $0.55553 \pm 0.00128$ \\
4 & Third scenario & $(0.55478 \leq \mathrm{k}-\mathrm{eff} \leq 0.55553)$ \\
& & \pm 0.00128 \\
\hline
\end{tabular}

Table 4 shows that at the initial state, the storage facility 1 is in sub-critical condition ( $\mathrm{k}$-eff $=$ $0.48171 \pm 0.00155)$. Condition storage facility 1 is safe because it is very far from the critical condition $(\mathrm{k}$-eff $=1)$. Table 4 also shows that the storage facility 1 remains sub-critical after adding 
2 storage shelves. The largest sub-critical condition is reached when the entire storage racks filled with depleted uranium metal container as many as 36 pieces ( $\mathrm{k}$-eff $=0.55553 \pm 0.00128$ ).

Table 5. Criticality level in storage facility 2

\begin{tabular}{clc}
\hline No. & \multicolumn{1}{c}{ Scenario } & k-eff \\
\hline 1 & Initial current condition & $0.12443 \pm 0.00026$ \\
2 & First scenario & $0.56036 \pm 0.00134$ \\
3 & Second scenario & $0.50841 \pm 0.00117$ \\
4 & Third scenario & $(0.50841 \leq \mathrm{k}$-eff $\leq$ \\
& & $0.56036) \pm 0.00134$ \\
\hline
\end{tabular}

From Table 5, it appears that the initial conditions of the storage facility are also sub-critical (k-eff $=0.12443 \pm 0.00026$ ). Of the three scenarios fuel storage in the storage rack, the largest criticality condition is reached in the second shelf, which is filled with U3O8 as many as 16 containers $(\mathrm{k}$-eff $=0.56036 \pm 0.00134)$.

Table 6. Criticality level in storage facility 3

\begin{tabular}{clc}
\hline No. & \multicolumn{1}{c}{ Scenario } & k-eff \\
\hline 1 & Initial current condition & $0.72995 \pm 0.00166$ \\
2 & First scenario & $0.96509 \pm 0.00132$ \\
\hline
\end{tabular}

Table 6 shows that the initial condition at the storage facility 3 is in the sub-critical condition with k-eff $=(0.72995 \pm 0.00166)$. Subcritical stay remains after the entire shelf filled with $\mathrm{U}_{3} \mathrm{Si}_{2}$ as many as 36 containers with k-eff $=0.96509 \pm 0.00132$.

Based on Table 4 to Table 6 , it can be seen that the largest sub-critical condition in the storage facility 3 . Based on the results it can be concluded that the entire three storage facilities in sub-critical conditions even with additional storage racks.

The fuel storage management was made based on the results. The goal of the management is so that each container position can be known in the storage area as well as the amounts of uranium inside the container is traceable. Uranium stoprage facility system management is accomplished through numbering the storage facilities. The container numbering is proposed as follows:

where:

\section{Container Number $=$ FN-D/RM-YX}

$\mathrm{F} \quad=$ Storage fasility

$\mathrm{N}=$ Storage fasility $1 / 2 / 3$

$\mathrm{D} / \mathrm{R}=$ Ground $/$ Rack

$\mathrm{M} \quad=$ Base or Rack $1 / 2$

$\mathrm{Y}=$ Front view of the foremost $1 / 2 / 3$

$\mathrm{X} \quad=$ Side view of the leftmost. 1/2/3/4/5/6

Example:

A container is in storage facility 2. an place on the second rack in position number 2 from the front and the third from the left. For this condition the Number of container is namely F2-R2-23

Monitoring Cards here after is devised to monitor the container as well as materials such in Tabel 7.

Table 7. Card monitoring uranium materials

Container Number: F2-R2-23

\begin{tabular}{|c|c|c|c|c|c|c|c|}
\hline No. & Date & $\begin{array}{l}\text { Type of } \\
\text { Uranium }\end{array}$ & $\begin{array}{c}\text { Initial } \\
\text { Mass } \\
(\mathrm{Kg}) \\
\end{array}$ & $\begin{array}{l}\text { Addition Mass } \\
\qquad(\mathrm{kg})\end{array}$ & $\begin{array}{l}\text { Taken-out } \\
\text { Mass (kg) }\end{array}$ & $\begin{array}{c}\text { End } \\
\text { Condition } \\
\text { Mass (Kg) }\end{array}$ & $\begin{array}{c}\text { Name/ } \\
\text { sign }\end{array}$ \\
\hline 1 & $02 / 01 / 17$ & $\mathrm{U}_{3} \mathrm{O}_{8}$ & 5.50 & - & - & 5.50 & \\
\hline 2 & $10 / 03 / 17$ & $\mathrm{U}_{3} \mathrm{O}_{8}$ & 5.50 & 2.75 & - & 8.25 & \\
\hline 3 & $15 / 03 / 17$ & $\mathrm{U}_{3} \mathrm{O}_{8}$ & 8.25 & - & 1.00 & 7.25 & \\
\hline
\end{tabular}


With the monitoring card as seen in Table 7, each container and its contents can be monitored and traced the amount of uranium that exists, and it history when added, retrieved, and is done by anyone. Thus it will be avoided uranium discharge to place unwanted and which will be hazardoues to workers, public and environtment because it is polluted by uranium.

\section{CONCLUSION}

The criticality Analysis of the storage facility has been completed. Criticality analysis results on the initial conditions for the three storage facilities are $\mathrm{k}$-eff $<1$. As for the three storage facilities after the addition of storage racks resulted the lcriticality level in storage facilities 1,2 and 3 are also $\mathrm{k}$-eff $<1$. All the storage facilities in a safe condition where $\mathrm{k}$-eff values still far from critical condition at a price of k-eff $=1.00$. The results are then used as the basis for the uranium materials management. The uranium material storage management based on the analysis was created to monitor the uranium material from traceability and illicit trafficking. Apart from that, the analysis results can be used as the basis to get the license of uranium material management from the regulatory body (BAPETEN).

\section{ACKNOWLEDGEMENT}

This research funded by PTKRN DIPA budget for fiscal year 2015. Our gratitude goes to the Head of PTKRN for use the DIPA budget. Thanks are also extended to colleagues Dr. M. Budi Setiawan from PTKRN-BATAN and Dr. Ing. Kusnanto from PT. INUKI (Persero) who helped researchers make this research done successfully.

\section{REFERENCES}

1. X-5 Monte Carlo Team MCNP - A General Monte Carlo N-Particle Transport Code, Version 5. Los Alamos Nuclear Laboratory. Los Alamos - USA: 2005.

2. Kastanya D. Critical mass calculations using MCNP: An academic exercise. Ann. Nucl. Energy. 2015. 75:228-231.

3. Alloni D., Borio Di Tigliole A., Cammi A., Chiesa D., Clemenza M., Magrotti G., et al. Final characterization of the first critical configuration for the TRIGA Mark II reactor of the University of Pavia using the Monte Carlo code MCNP. Prog. Nucl. Energy. 2014. 74:129-135.

4. Robinson M.L., DeBey T.M., Higginbotham J.F. Benchmarking criticality analysis of TRIGA fuel storage racks. Appl. Radiat. Isot. 2017. 119:16-22.

5. Wang M.-J., Sheu R.-J., Peir J.-J., Liang J.-H. Criticality calculations of the HTR-10 pebble-bed reactor with SCALE6/CSAS6 and MCNP5. Ann. Nucl. Energy. 2014. 64:1-7.

6. Wang M.-J., Peir J.-J., Sheu R.-J., Liang J.-H. Effects of geometry homogenization on the HTR-10 criticality calculations. Nucl. Eng. Des. 2014. 271:356-360.

7. Setiawati E., Oktajianto H., Richardina V., Endro S J. Analysis loading height of HTR (High Temperature Reactor) core to obtain criticality of reactor. Int. J. Sci. Eng. 2015. 9:113-116.

8. Oktajianto H., Setiawati E., Richardina V. Modelling of HTR (High Temperature Reactor) Pebble-Bed $10 \mathrm{MW}$ to determine criticality as a variations of enrichment and radius of the Fuel (Kernel) with the Monte Carlo code MCNP4C. Int. J. Sci. Eng. 2015. 8:42-46.

9. Ho H.Q., Honda Y., Goto M., Takada S. Numerical investigation of the Random Arrangement Effect of coated fuel particles on the Criticality of HTTR fuel compact using MCNP6. Ann. Nucl. Energy. 2017. 103:114-121.

10. Zuhair, Suwoto, Irianto I.D. Pemodelan teras untuk analisis perhitungan konstanta multiplikasi reaktor HTR-PROTEUS. Tri Dasa Mega. 2010. 12(2):91-102. 
11. Sudarmono, Suwoto, Hery A. Sensitivitas pengayaan dan fraksi packing partikel triso dalam bahan bakar Pebble terhadap k-inf sebagai dasar disain konseptual RGTT200K. J. Ilmu Daur Bahan Bakar Nuklir URANIA. 2013. 19:25-38.

12. Odoi H.C., Akaho E.H.K., Jonah S.A., Abrefah R.G., Ibrahim V.Y., Al E.T. Study of criticality safety and neutronic Performance for a 348-Fuel-Pin Ghana Research Reactor1 LEU core using MCNP code. World J. Nucl. Sci. Technol. 2014. 4:46-52.

13. Mosteller R. Comparison of ENDF / B-VII . 1 and ENDF / B-VII . 0 results for the expanded criticality validation suite for MCNP and for selected additional criticality benchmarks. Nucl. Data Sheets. 2014. 118:442-445.

14. Zerovnik G., Podvratnik M., Snoj L. On normalization of fluxes and reaction rate in MCNP criticality calculation. Ann. Nucl. Energy. 2014. 63:126-128.

15. Hughes C.R., Pelaez O., Schubring D., Jordan K.A. Multi-physics analysis of a supercritical water reactor with improved MCNP modeling. Nucl. Eng. Des. 2014. 270:412-420.

16. NUKEM GMBH, Basic and Detail Engineering Process - element fabrication plan for Badan Tenaga Atom Nasional - NUKEM VT-No 2.008, HANAU, Germany, 1983 